\title{
Optimization of Nitric Acid Leaching of Rare Earth Elements From Moroccan Natural Phosphate
}

\author{
Marouane Amine ${ }^{1}$, Fatima Asafar ${ }^{1}$, Latifa Bilali ${ }^{1}$, Mehdi Nadifiyine ${ }^{1}$ \\ ${ }^{1}$ Laboratoire des Sciences des Matériaux et Optimisation des Procédés, Faculté des Sciences Semlalia, Université Cadi \\ Ayyad, Avenue Prince Moulay Abdellah, B.P. 2390, 40000 Marrakech, Maroc \\ Correspondence: Marouane Amine, Laboratoire des Sciences des Matériaux et Optimisation des Procédés, Faculté des \\ Sciences Semlalia, Université Cadi Ayyad, Avenue Prince Moulay Abdellah, B.P. 2390, 40000 Marrakech, Maroc. \\ E-mail: marouane.amin@gmail.com
}

Received: May 17, 2020 Accepted: Oct. 30, 2020 Online Published: Nov. 16, 2020

doi:10.5539/ijc.v13n1p1 URL: https://doi.org/10.5539/ijc.v13n1p1

\begin{abstract}
Phosphate is a very important natural resource in Morocco and one of the secondary resources of rare earth elements. Our study is particularly interested in Youssoufia phosphate, which contains $228.77 \mathrm{ppm}$ of rare earth elements ( $\Sigma$ REEs). The purpose of our work is to study the influence of different parameters (acid concentration, solid/liquid ratio and temperature) in order to determine the optimal conditions for the leaching of rare earths. An experimental design (Doehlert matrix) has been drawn up to optimize the experimental conditions of the leaching. All tests were made with nitric acid at different concentrations varying between $1.5 \mathrm{M}$ and $4.5 \mathrm{M}$ with a solid/liquid ratio of $1 / 12$ to $1 / 6$; reaction temperature and duration are respectively $20^{\circ} \mathrm{C}$ to $80{ }^{\circ} \mathrm{C}$ and $60 \mathrm{~min}$. The optimal conditions are obtained when using $69^{\circ} \mathrm{C}$ as temperature, 4.1 $\mathrm{M}$ as acid concentration and $1 / 9$ as solid/liquid ratio.
\end{abstract}

Keywords: doehlert experimental design, acid leaching, optimization, phosphate rock, rare earth

\section{Introduction}

The earth's crust contains a significant number of phosphate deposits of igneous and sedimentary origins (Loh et al., 2016). Morocco, with its significant share of world phosphate stock, is leading exportation of phosphate and its derivatives. The country's global market share is over 30\% (Hakkou, Benzaazoua, \& Bussière, 2016). Moroccan phosphates are the most important both in quantity and quality; these are located in the Gantour (Youssoufia and Benguérir), Messkala (Chichaoua), Oued Eddahab (Boucraâ) and Ouled Abdoun (Khouribga) deposits (Bilali, Benchanaa, Outzourhit, \& Mokhlisse, 2009). Sedimentary deposits of natural phosphates are mainly composed of apatite of the general formula: $\mathrm{M}_{10}\left(\mathrm{ZO}_{4}\right)_{6} \mathrm{X}_{2}$ with $\mathrm{M}=\mathrm{Ca}, \mathrm{Sr}, \mathrm{REE} \ldots$... $\mathrm{Z}=\mathrm{P}, \mathrm{As}, \mathrm{Si}, \ldots ; \mathrm{X}=\mathrm{F}, \mathrm{OH}, \mathrm{Cl} \ldots \ldots . .(\mathrm{Pereira}$, 2003). In some carbonates, apatite minerals contain most of the rare earths elements (REE), fluorine and strontium. Fluorapatite is the most common phosphorus mineral and is always enriched with light rare earths. Rare earth deposits occur in a wide variety of igneous, sedimentary and metamorphic rocks (Koltun, \& Tharumarajah, 2014). Literature reports that the phosphate matrix, xenotime and monazite minerals contain rare earths that are extracted by acid or basic leaching (Pereira, 2012). Several studies have been focused on the use of different acids for the extraction of rare earths from various ores including phosphates (Zhang, 2014; Soltani et al., 2019). Recently, several studies have been carried out on the recovery of rare earths from secondary sources, such as natural phosphates, containing minute quantities of rare earths ; among these studies, we cite that of Wu et al. (2019) which focuses on the optimization of rare earth leaching, in the form of mixed oxides, from Youssoufia natural Moroccan phosphate. The observation of the effects of all variables: acid nitric concentration, temperature and solid/liquid ratio coded respectively $\mathrm{X}_{1}, \mathrm{X}_{2}$ and $\mathrm{X}_{3}$ and their interactions are of paramount importance to understand the acid leaching process. The experimental design has been used to control the different factors that influence the leaching process to optimize the experimental conditions. The advantage of this method is to reduce the number of experiments that study the interactions between the chosen factors (Said K.A.M, \& Amin M.A.M, 2016). In Nemrod software the complete $3^{3}$ factorial design is a simple and important statistical tool. Influencing factors are optimized using the Surface of Response method and multi-criteria optimization with Doehlert design and desirability function (Pereira, 2012; Said K.A.M, \& Amin M.A.M, 2016). 


\section{Experimental}

\subsection{Materials}

The experimental study is based on phosphate that was provided by CERPHOS (Center for studies and research on phosphates of OCP group). The used phosphate is from the Youssoufia deposit (Gantour Basin). This phosphate is apatitic. Fluorapatite $\left(\mathrm{Ca}_{10}\left(\mathrm{PO}_{4}\right)_{6} \mathrm{~F}_{2}\right)$ is the most stable compound of natural phosphate. The general properties of this ore and the structure of the fluorapatite have been described in previous works (Bilali, Benchanaa, Outzourhit \& Mokhlisse, 2009; M. Amine, Asafar, Bilali \& Nadifiyine, 2019).

\subsection{Experimental Device and Method}

\subsubsection{Experimental Part}

The homogeneity of the material and its particles size is an important parameter that should be well controlled. For this, we worked with particle size $<80 \mu \mathrm{m}$. In this study of nitric leaching, we used homogeneous samples from Youssoufia natural phosphates of OCP. The objective of the leaching manipulations is to study the influence of certain parameters (acid concentration, solid/liquid ratio and temperature) in order to define their optimal values allowing the maximum dissolution of rare earths. For the acid leaching experiments, solid phosphate and acid mixture was prepared in a $250 \mathrm{ml}$ Erlenmeyer flask and heated on a temperature-controlled hotplate. The tests were made with nitric acid concentrations varying between $1.5 \mathrm{~mol} / \mathrm{L}$ and $4.5 \mathrm{~mol} / \mathrm{L}$ with a solid/liquid ratio of $1 / 12$ to $1 / 6$. The reaction temperature values are between $20^{\circ} \mathrm{C}$ and $80{ }^{\circ} \mathrm{C}$ while the duration of the reaction and Agitator speed are fixed at $60 \mathrm{~min}$ and $500 \mathrm{rpm}$ respectively. The Table 1 presents the list of all the factors adopted by our study that influence nitric leaching.

Table 1. Experimental domain for the Doehlert design

\begin{tabular}{ccccc}
\hline & Factor $(\mathrm{XI})$ & $\mathrm{HNO}_{3}(\mathrm{~mol} / \mathrm{L})$ & Temperature $\left({ }^{\circ} \mathrm{C}\right)$ & Ratio S/L \\
\hline Level 1 & -1 & 1.5 & 20 & $1 / 12$ \\
Level 2 & 0 & 3 & 50 & $1 / 8$ \\
Level 3 & +1 & 4.5 & 80 & $1 / 6$ \\
\hline
\end{tabular}

\subsubsection{Design of Experiments}

The response surface methodology (RSM) was used to optimize operating conditions allowing maximum dissolution of the rare earths (Liu, \& Wang, 2007). The three factors influencing this dissolution (acid concentration, temperature and solid/liquid ratio) are coded respectively $\left(\mathrm{X}_{1}, \mathrm{X}_{2}\right.$, and $\left.\mathrm{X}_{3}\right)$ and the response represented by the concentration of rare earths in ppm is (Y). We worked with three factors that correspond to 17 tests performed including five to calculate both the error variance and the reproducibility of the test data. A polynomial model of second degree was used. The model can be written as:

$$
\begin{gathered}
Y=b_{0}+b_{1} * X_{1}+b_{2} * X_{2}+b_{3} * X_{3}+b_{1-1} *\left(X_{1} * X_{1}\right) \\
+b_{2-2} *\left(X_{2} * X_{2}\right)+b_{3-3} *\left(X_{3} * X_{3}\right)+b_{1-2} *\left(X_{1} * X_{2}\right) \\
+b_{1-3} *\left(X_{1} * X_{3}\right)+b_{2-3} *\left(X_{2} * X_{3}\right) .
\end{gathered}
$$

Y: studied answer; $\mathrm{X}_{\mathrm{i}}$ : investigated factor (i varies from 1 to 3 ); $\mathrm{b}_{0}$ : a constant; $\mathrm{b}_{\mathrm{i}}$ : main effect of factor $\mathrm{i}$.

The experimental design was developed using Nemrod software (New Efficient Methodology for Research using Optimal Design) (Mathieu, Mony, \& Phan Tan Luu, 2000). The experimental Doehlert design was randomized to minimize the effects of uncontrolled factors.

\subsection{Analysis and Characterization Techniques}

Crude phosphate samples were characterized by X-ray diffraction, scanning electron microscopy (SEM) and inductively coupled plasma mass spectrometry (ICP-AES), while nitric leaching solutions were analyzed by ICP-AES only.

\section{Results and Discussion}

\subsection{Analysis and Characterization of Rock Phosphate}

\subsubsection{Inductively Coupled Plasma Atomic Emission Spectroscopy (ICP-AES)}

REEs contents of phosphate are given in table 2 (M. Amine, Asafa,Bilali, \& Nadifiyine, 2019). Abundant elements are: Yttrium (143 ppm), Lanthanum (24.06 ppm) and Neodymium (17.52 ppm). All phosphate ores contain varying amounts of rare earths; table 3 shows the contents of typical REEs, uranium and thorium contained in the Youssoufia phosphate ore (Rollat, 2016). 
Table 2. Rare earths Contents in Youssoufia rock phosphate

\begin{tabular}{ll}
\hline Element & ppm \\
\hline $\mathrm{Y}$ & 143 \\
$\mathrm{La}$ & 24.06 \\
$\mathrm{Ce}$ & 13 \\
$\mathrm{Pr}$ & 3.626 \\
$\mathrm{Nd}$ & 17.52 \\
$\mathrm{Sm}$ & 3.681 \\
$\mathrm{Eu}$ & 1.008 \\
$\mathrm{Gd}$ & 5.143 \\
$\mathrm{~Tb}$ & 0.8387 \\
$\mathrm{Dy}$ & 5.672 \\
$\mathrm{Ho}$ & 1.303 \\
$\mathrm{Er}$ & 4.315 \\
$\mathrm{Tm}$ & 0.6205 \\
$\mathrm{Yb}$ & 4.2 \\
$\mathrm{Lu}$ & 0.7843 \\
$\mathrm{SREE}$ & 228.77 \\
\hline
\end{tabular}

Table 3. Uranium, thorium and rare earths contents in Youssoufia rock phosphate (Rollat, 2016).

\begin{tabular}{ll}
\hline Element & $($ ppm) \\
\hline $\mathrm{La}_{2} \mathrm{O}_{3}$ & 80 \\
$\mathrm{CeO}_{2}$ & 110 \\
$\mathrm{Nd}_{2} \mathrm{O}_{3}$ & 20 \\
$\mathrm{Sm}_{2} \mathrm{O}_{3}$ & 13.5 \\
$\mathrm{Eu}_{2} \mathrm{O}_{3}$ & 1.5 \\
$\mathrm{~Tb}_{4} \mathrm{O}_{7}$ & 3.5 \\
$\mathrm{Y}_{2} \mathrm{O}_{3}$ & 110 \\
$\mathrm{Sc}_{2} \mathrm{O}_{3}$ & 8.5 \\
$\mathrm{Th}_{2} \mathrm{O}_{3}$ & 3.5 \\
$\mathrm{U}_{3} \mathrm{O}_{8}$ & 125 \\
\hline
\end{tabular}

3.1.2 X-ray Diffraction Characterization (XRD)

Youssoufia phosphate has been characterized by X-ray diffraction. The majority of the diffraction lines observed are attributed to the apatitic phase (Figure 1). Other secondary phases are also present and attributed to quartz, calcite and dolomite (Aouad, Benchanaa, Mokhlisse, \& Ounas, 2004; Aouad, Benchanaa, Mokhlisse, \& Arafan, 2002). 


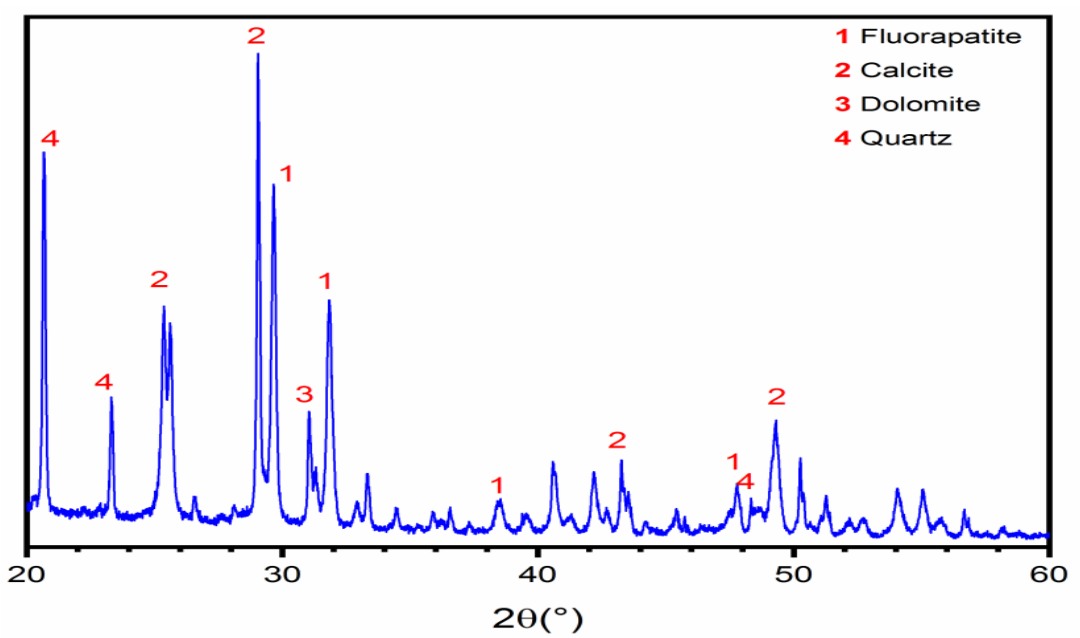

Figure 1. X-ray diffraction pattern of the raw phosphate

\subsubsection{Scanning Electron Microscopy (SEM) and dispersive X-Ray Energy (EDX)}

The observation by a scanning electron microscope (Figure 2-a) coupled with dispersive X-ray energy analysis (Table 4) shows that Youssoufia phosphate rock before attack with nitric acid consists essentially of irregularly shaped phosphate particles and sometimes rounded. This variety of particles is explained, in addition to apatite, by the presence of bone debris, organic debris as well as quartz grains. We can observe, after treatment (figure 2-b), that the majority of the particles have disappeared. the surface of the material thus obtained exhibits a certain homogeneity while showing pores and cracks. Scanning electron microscopy analyses allowed us to observe the same crystalline compounds as those identified by X-ray diffraction (M. Amine, Asafar, Bilali, \& Nadifiyine, 2019).
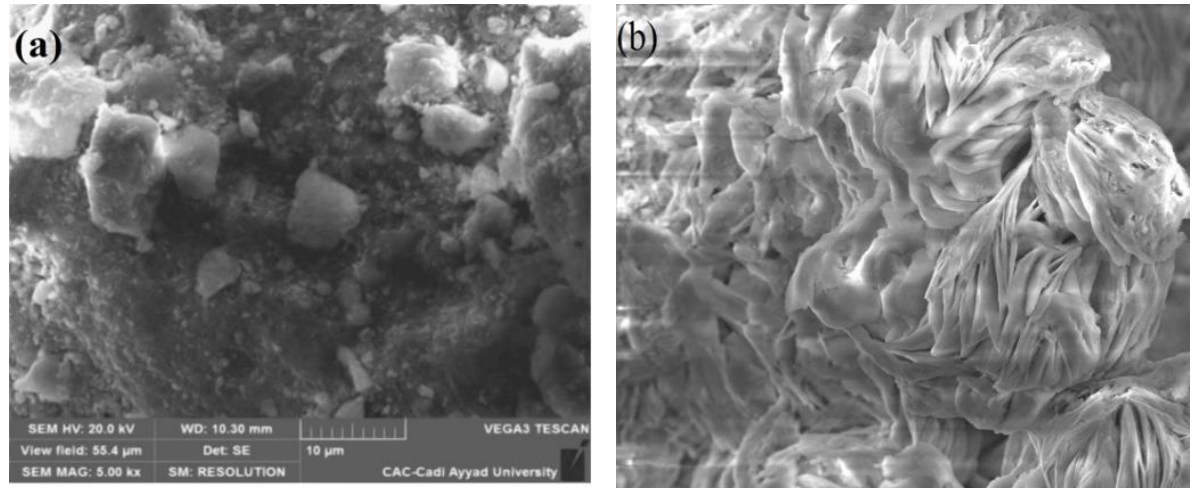

Figure 2. Morphological observations of the natural phosphate surface before (a) and after (b) treatment. 
Table 4. Chemical composition of Youssoufia natural phosphate

\begin{tabular}{lllll}
\hline Element & \multicolumn{2}{l}{ Before treatement } & \multicolumn{2}{l}{ After treatement } \\
\cline { 2 - 5 } & $10 \mu \mathrm{m}$ & \multicolumn{3}{l}{$10 \mu \mathrm{m}$} \\
\cline { 2 - 5 } & wt. \% & At \% & wt. \% & At \% \\
\hline $\mathrm{C}$ & 12.86 & 20.90 & 2.90 & 5.63 \\
$\mathrm{O}$ & 41.86 & 51.07 & 35.14 & 51.31 \\
$\mathrm{~F}$ & 5.59 & 5.74 & 3.68 & 4.53 \\
$\mathrm{Na}$ & 1.38 & 1.17 & 0.72 & 0.73 \\
$\mathrm{Y}$ & 0.46 & 0.20 & - & - \\
$\mathrm{Mg}$ & 0.76 & 0.61 & 0.42 & 0.40 \\
$\mathrm{Al}$ & 0.86 & 0.62 & 0.10 & 0.09 \\
$\mathrm{Si}$ & 2.17 & 1.51 & 0.11 & 0.09 \\
$\mathrm{P}$ & 10.03 & 6.32 & 3.18 & 2.05 \\
$\mathrm{~S}$ & 1.23 & 0.75 & 0.19 & 0.14 \\
$\mathrm{~K}$ & 0.11 & 0.05 & - & - \\
$\mathrm{Ca}$ & 22.97 & 11.19 & 22.17 & 12.92 \\
$\mathrm{~V}$ & 0.09 & 0.03 & - & - \\
$\mathrm{Fe}$ & 0.1 & 0.04 & - & - \\
\hline
\end{tabular}

\subsection{Analysis of Y Response}

Analysis of Y responses from the results listed in table 6 lets to see that the REEs concentration varies between 72.9 ppm (experience 8) and 202.5 ppm (experience 3). The estimation of coefficients (bi) of the postulated model (Eq.1) was determined by the least-squares method using Nemrod software. Main effects of factors (bi) were performed from statistical tests on the coefficients. The mathematical model was validated by verifying the correlation coefficient $\left(\mathrm{R}^{2}\right)$ (Baçaoui, Yaacoubi, \& Dahbi et al., 2001). When $\mathrm{R}^{2}$ values are close to 1 the model offers an appropriate explanation of the variability of experimental to predicted values (Boujounoui et al., 2018). The difference between these two types of values was explained by the model. To calculate the proportion of the total observed variability, an adjusted determination coefficient $\left(\mathrm{R}^{2} \mathrm{Adj}\right)$ was employed. After validation, and to graphically illustrate the surfaces response, different models were used.

\subsubsection{Study of the Estimates and Statistics of the Coefficients}

From table 7, we can see that all of the factors are involved in different interactions. Using values of these factors, the Eq. 1 becomes:

$$
\begin{gathered}
\mathrm{Y}=124.6051+43.7288 \mathrm{X}_{1}+27.6329 \mathrm{X}_{2}+7.0512 \mathrm{X} 3+13.6574\left(\mathrm{X}_{1} * \mathrm{X}_{1}\right) \\
5.5271\left(\mathrm{X}_{2} * \mathrm{X}_{2}\right)-18.3288\left(\mathrm{X}_{3} * \mathrm{X}_{3}\right)+50.0560\left(\mathrm{X}_{1} * \mathrm{X}_{2}\right) \\
-6.7875\left(\mathrm{X}_{1} * \mathrm{X}_{3}\right)-61.9555\left(\mathrm{X}_{2} * \mathrm{X}_{3}\right)
\end{gathered}
$$

The correlation between the theoretical and experimental responses was satisfactory: $R^{2}=0.91$ and $R^{2} A d j=0.80$.

\subsubsection{Three-Dimensional (3D) Response Surface and Iso-Response Curves (2D)}

$3 \mathrm{D}$ and 2D response surface plots were used to visualize the relationship between the responses (Y), the experimental levels of each variable and the type of interactions between variables to deduce the operating conditions leading to the optimal response. The Table 6 shows that the highest response $(202.500 \mathrm{ppm})$ was achieved with the greatest levels of $\mathrm{HNO}_{3}\left(\mathrm{X}_{1}\right)$ and Temperature $\left(\mathrm{X}_{2}\right)$.

\subsubsection{Factorial Design, Experimental Conditions and Experimental Results Y (REE)}

To estimate the coefficients of the model, Doehlert design was applied using Nemrod software. This design permits to represent the responses studied in all experimental domains of the three factors $\mathrm{HNO}_{3}$ concentration, temperature and solid/liquid ratio. Doehlert experimental design and corresponding experimental conditions are given in Table 5). 
Table 5. Doehlert experimental design and operating conditions.

\begin{tabular}{lcccccc}
\hline $\mathbf{N}^{\circ}$ Exp & & \multicolumn{2}{c}{ Design of Experiment } & \multicolumn{2}{c}{ Operating conditions } \\
& $\mathrm{X}_{1}$ & $\mathrm{X}_{2}$ & $\mathrm{X}_{3}$ & $\begin{array}{c}\mathrm{HNO}_{3} \\
(\mathrm{~mol} / \mathrm{L})\end{array}$ & $\begin{array}{c}\text { Temperature } \\
\left(\mathrm{C}^{\circ}\right)\end{array}$ & Ratio S/l \\
\hline $\mathbf{1}$ & & & & 4.5 & 50 & 0.12 \\
$\mathbf{2}$ & 1.00000 & 0.00000 & 0.00000 & 1.5 & 50 & 0.12 \\
$\mathbf{3}$ & -1.00000 & 0.00000 & 0.00000 & 3.8 & 76 & 0.12 \\
$\mathbf{4}$ & 0.50000 & 0.86603 & 0.00000 & 2.3 & 24 & 0.12 \\
$\mathbf{5}$ & -0.50000 & -0.86603 & 0.00000 & 3.8 & 24 & 0.12 \\
$\mathbf{6}$ & 0.50000 & -0.86603 & 0.00000 & 2.3 & 76 & 0.12 \\
$\mathbf{7}$ & -0.50000 & 0.86603 & 0.00000 & 3.8 & 59 & 0.15 \\
$\mathbf{8}$ & 0.50000 & 0.28868 & 0.81650 & 2.3 & 41 & 0.09 \\
$\mathbf{9}$ & -0.50000 & -0.28868 & -0.81650 & 3.8 & 41 & 0.09 \\
$\mathbf{1 0}$ & 0.50000 & -0.28868 & -0.81650 & 3.0 & 67 & 0.09 \\
$\mathbf{1 1}$ & 0.00000 & 0.57735 & -0.81650 & 2.3 & 59 & 0.15 \\
$\mathbf{1 2}$ & -0.50000 & 0.28868 & 0.81650 & 3.0 & 33 & 0.15 \\
$\mathbf{1 3}$ & 0.00000 & -0.57735 & 0.81650 & 3.0 & 50 & 0.12 \\
$\mathbf{1 4}$ & 0.00000 & 0.00000 & 0.00000 & 3.0 & 50 & 0.12 \\
$\mathbf{1 5}$ & 0.00000 & 0.00000 & 0.00000 & 3.0 & 50 & 0.12 \\
$\mathbf{1 6}$ & 0.00000 & 0.00000 & 0.00000 & 3.0 & 50 & 0.12 \\
$\mathbf{1 7}$ & 0.00000 & 0.00000 & 0.00000 & 3.0 & 50 & 0.12 \\
\hline & 0.00000 & 0.00000 & 0.00000 & & & \\
\hline
\end{tabular}

In order to interpret the results, the response surfaces were represented in the domains of interest of acid concentration, solid/liquid ratio, and temperature using Nemrod software. Doehlert experimental design and experimental results are given in Table 6. 
Table 6. Doehlert experimental design and responses Y (Rare earth concentrations)

\begin{tabular}{lccccccc}
\hline $\mathrm{N}^{\circ}$ Exp & \multicolumn{3}{c}{ Design of Experiment } & \multicolumn{3}{c}{ Operating conditions } & Response \\
& $\mathrm{X}_{1}$ & $\mathrm{X}_{2}$ & $\mathrm{X}_{3}$ & $\begin{array}{c}\mathrm{HNO}_{3} \\
(\mathrm{~mol} / \mathrm{L})\end{array}$ & $\begin{array}{c}\text { Temperature } \\
\left(\mathrm{C}^{\circ}\right)\end{array}$ & Ratio S/l & $\mathrm{Y}$ \\
& & & & & & $(\mathrm{ppm})$ \\
\hline 1 & 1.00000 & 0.00000 & 0.00000 & 4.5 & 50 & 0.12 & 182.010 \\
2 & -1.00000 & 0.00000 & 0.00000 & 1.5 & 50 & 0.12 & 94.515 \\
3 & 0.50000 & 0.86603 & 0.00000 & 3.8 & 76 & 0.12 & 202.500 \\
4 & -0.50000 & -0.86603 & 0.00000 & 2.3 & 24 & 0.12 & 105.180 \\
5 & 0.50000 & -0.86603 & 0.00000 & 3.8 & 24 & 0.12 & 124.800 \\
6 & -0.50000 & 0.86603 & 0.00000 & 2.3 & 76 & 0.12 & 96.180 \\
7 & 0.50000 & 0.28868 & 0.81650 & 3.8 & 59 & 0.15 & 138.450 \\
8 & -0.50000 & -0.28868 & -0.81650 & 2.3 & 41 & 0.09 & 72.900 \\
9 & 0.50000 & -0.28868 & -0.81650 & 3.8 & 41 & 0.09 & 88.500 \\
10 & 0.00000 & 0.57735 & -0.81650 & 3.0 & 67 & 0.09 & 167.130 \\
11 & -0.50000 & 0.28868 & 0.81650 & 2.3 & 59 & 0.15 & 105.150 \\
12 & 0.00000 & -0.57735 & 0.81650 & 3.0 & 33 & 0.15 & 119.835 \\
13 & 0.00000 & 0.00000 & 0.00000 & 3.0 & 50 & 0.12 & 121.815 \\
14 & 0.00000 & 0.00000 & 0.00000 & 3.0 & 50 & 0.12 & 127.650 \\
15 & 0.00000 & 0.00000 & 0.00000 & 3.0 & 50 & 0.12 & 121.530 \\
16 & 0.00000 & 0.00000 & 0.00000 & 3.0 & 50 & 0.12 & 124.515 \\
17 & 0.00000 & 0.00000 & 0.00000 & 3.0 & 50 & 0.12 & 127.515 \\
\hline
\end{tabular}

Table 7. Estimated values of the coefficients for the $Y$ responses

\begin{tabular}{lrll}
\hline Nom & Coefficient & Ecart-Type & Signif. \% \\
\hline $\mathrm{b}_{0}$ & 124.6051 & 1.3226479 & $<0.01 * * * 1$ \\
$\mathrm{~b}_{1}$ & 43.7288 & 1.4787653 & $<0.01 * * *$ \\
$\mathrm{~b}_{2}$ & 27.6329 & 1.4787617 & $<0.01 * * *$ \\
$\mathrm{~b}_{3}$ & 7.0512 & 1.4635234 & $0.854 * * 2$ \\
$\mathrm{~b}_{1-1}$ & 13.6574 & 2.4744477 & $0.526 * *$ \\
$\mathrm{~b}_{2-2}$ & 5.5271 & 2.4744214 & 8.9 \\
$\mathrm{~b}_{3-3}$ & -18.3288 & 2.2748659 & $0.129 * *$ \\
$\mathrm{~b}_{1-2}$ & 50.0560 & 3.4150441 & $0.0126 * * *$ \\
$\mathrm{~b}_{1-3}$ & -6.7875 & 3.7787925 & 14.7 \\
$\mathrm{~b}_{2-3}$ & -61.9555 & 3.7788248 & $<0.01 * * *$ \\
\hline
\end{tabular}

Graphic representations a, b, and c (Figure 3) of 2D and 3D response surface plots show that the main parameters that have a large influence on the rare earths lixiviation process adopted are: acid concentration and temperature which act positively on the response $\mathrm{Y}$ (by increasing their values the answer becomes more important). The solid/liquid ratio acts in the opposite direction (by increasing its value the answer becomes weaker).

\footnotetext{
1 Value $* * *$ Statistically significant at the level $<99.99 \%$.

2 Value **Statistically significant at the level $99 \%$.
} 

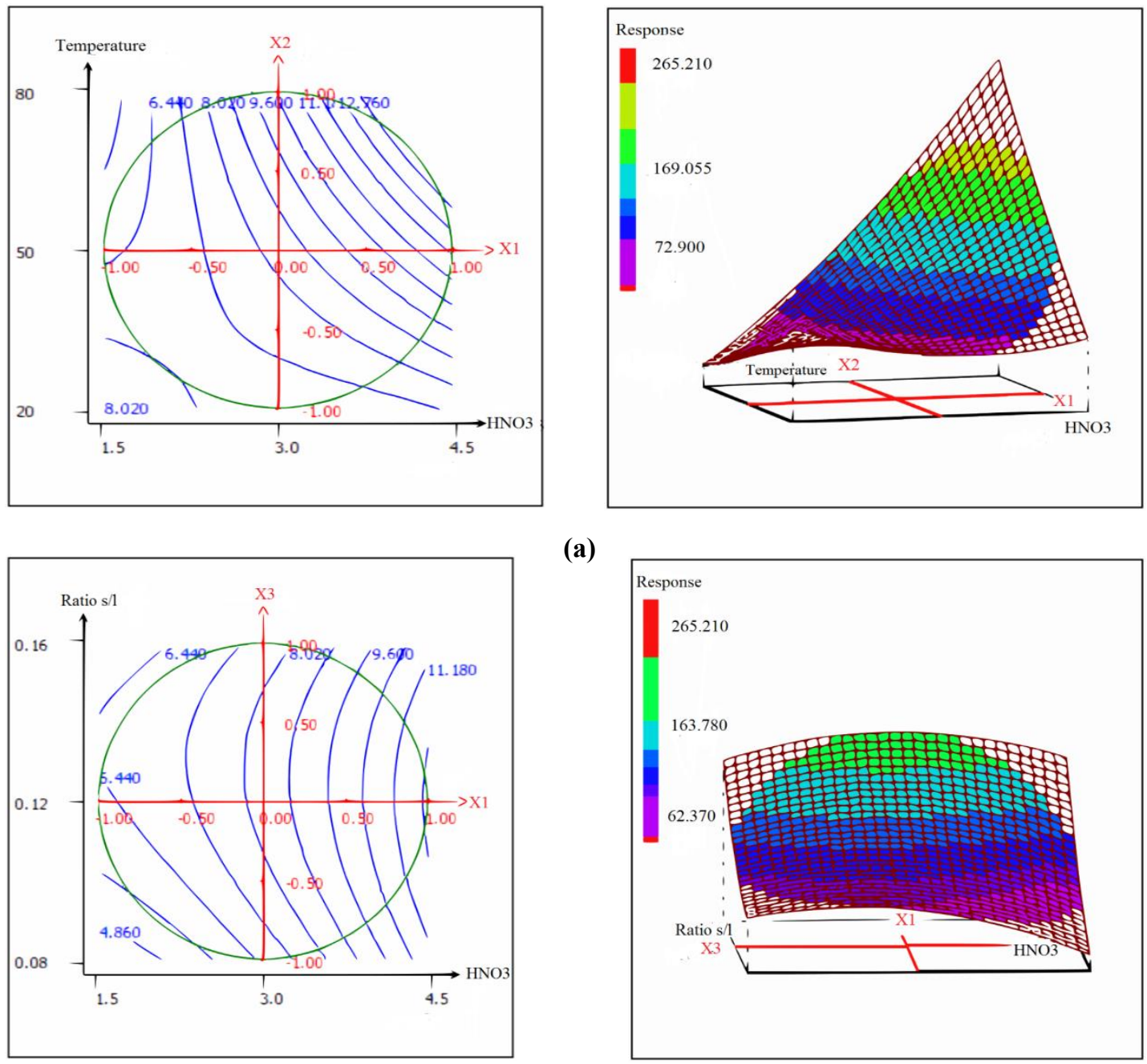

(a)
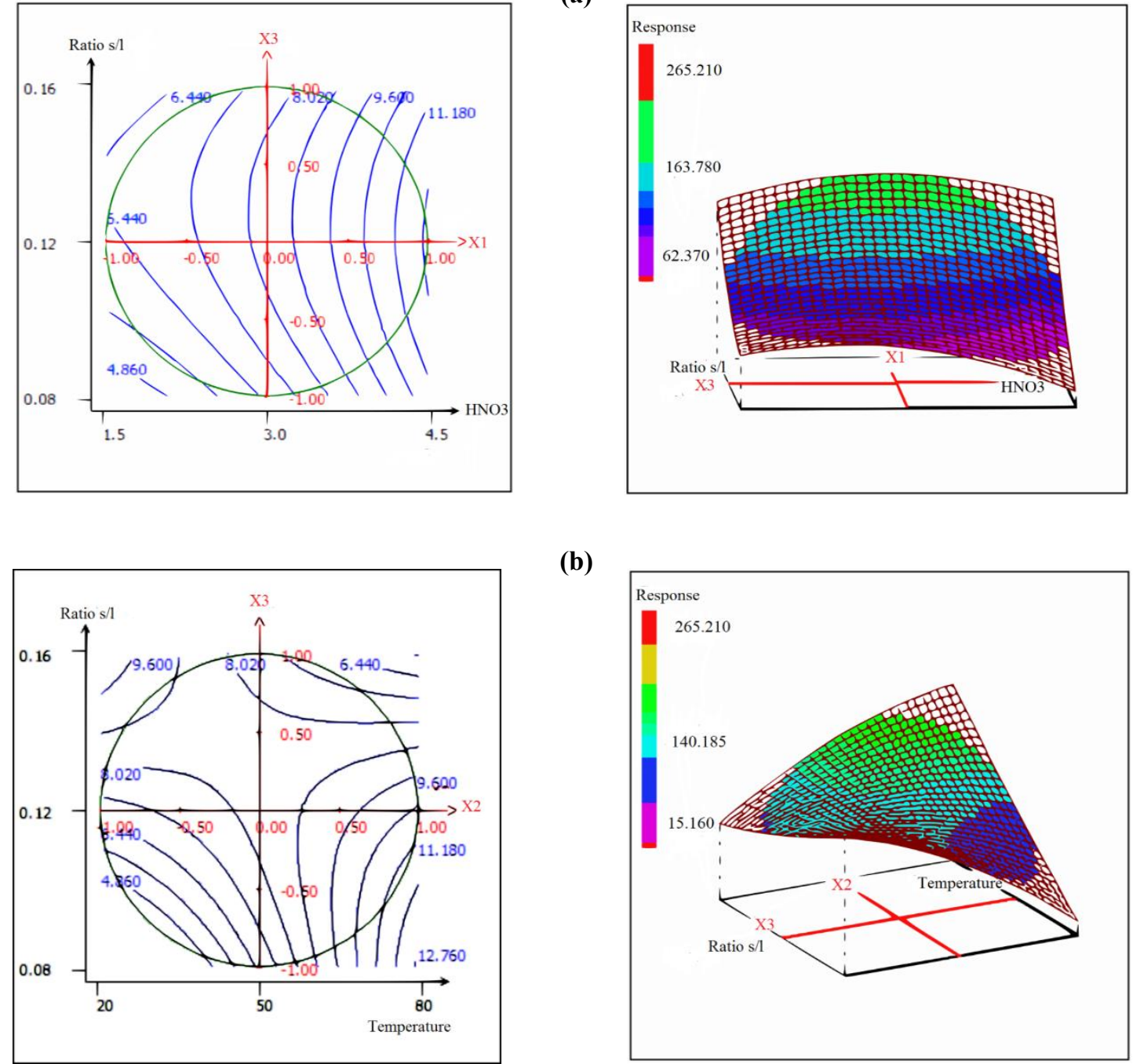

(b)

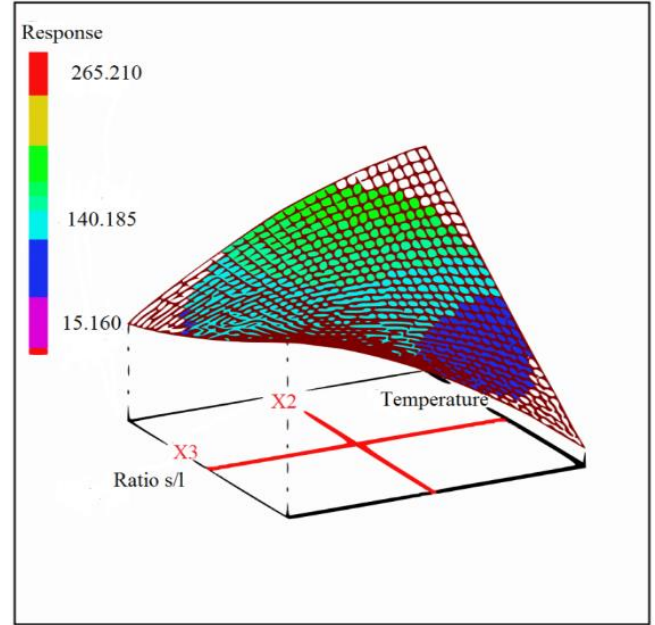

(c)

Figure 3. a: $\mathrm{HNO}_{3}\left(\mathrm{X}_{1}\right)$ and Temperature $\left(\mathrm{X}_{2}\right)$; b: $\mathrm{HNO}_{3}\left(\mathrm{X}_{1}\right)$ and $\mathrm{S} / \mathrm{L}$ ratio $\left(\mathrm{X}_{3}\right)$; c: Temperature $\left(\mathrm{X}_{2}\right)$ and $\mathrm{S} / \mathrm{L}$ ratio $\left(\mathrm{X}_{3}\right)$

The optimal operating conditions allowing the maximum lixiviation were studied by the response surface methodology. The attained solubilization of $83 \%$ for REE was obtained by the following conditions: acidification of the ore with a 4.1 
$\mathrm{mol} / \mathrm{L} \mathrm{HNO}_{3}$ solution, heating the mixture at $69{ }^{\circ} \mathrm{C}$ and using $1 / 9$ as solid/liquid ratio. Study with nitric acid gives a higher solubilization than study with hydrochloric acid (M. Amine, Asafa, Bilali, \& Nadifiyine, 2019).

\subsection{Optimization}

To determine optimal conditions acid concentration, solid/liquid ratio, and temperature in order to define the optimal parameters allowing the maximum dissolution of the rare earths, the responses are optimized simultaneously using the desirability function included in the Nemrod software. The desirability function varies in the interval $[0,1]$; the value 1 corresponds to the maximum satisfaction (desired value) and 0 corresponds to an unacceptable response (Hammas-Nasri, Horchani-Naifer, Férid, \& Barca, 2016 ; Maguana et al., 2018 ; Zhang, Gu, Ahmad, \& Huang, 2017 ; Chu et al., 2015). The maximum of the function D gives the best global compromise for all the responses in the studied domains and corresponds to optimal experimental conditions. All informations and results of the multi criteria optimization are given in Table 8. After calculation by the Nemrod software, the response surface corresponding to the maximum of the global desirability function $\mathrm{D}$ is obtained. At optimal conditions, the predicted values of the responses calculated from the model were determined. In order to validate the model, three experiments were conducted under the same optimal conditions. The difference between the experimental and the predicted values was found to be minimal which indicates the good accuracy of the model.

Table 8. Characteristics of maximum for response $\mathrm{Y}$

\begin{tabular}{lcllllll}
\hline Response & $\begin{array}{c}\text { Target } \\
\text { value }\end{array}$ & Weight & $\mathrm{di}(\%)^{3}$ & $\mathrm{di}_{\min }(\%)^{4}$ & $\mathrm{di}_{\max }(\%)^{5}$ & Cal. value $^{6}$ & Exp.value $^{7}$ \\
\hline Y= REE $(\mathrm{ppm})$ & 215.1 & 1 & 96.68 & 94.67 & 98.69 & 215.1 & 210 \\
Desirability & - & - & 96.68 & 94.67 & 98.69 & - & - \\
\hline
\end{tabular}

\section{Conclusions}

Doehlert experimental design was used to determine the optimal conditions of the phosphate rock dissolution in order to lixiviate rare earths using the response surface methodology. The rare earths content in Moroccan phosphate was determined by the ICP/AES technique. The attained solubilization of REE (83\%) was obtained by the following conditions: acidification of the ore by a $4.1 \mathrm{~mol} / \mathrm{L} \mathrm{HNO}_{3}$ solution at $69^{\circ} \mathrm{C}$ with a solid/liquid ratio of $1 / 9$. To achieve a leaching rate greater than $90 \%$, a second study could be performed to increase the acid concentration and temperature by more than $4.1 \mathrm{M}$ and $69^{\circ} \mathrm{C}$, respectively, and reduce the $\mathrm{S} / \mathrm{L}$ ratio by less than $1 / 9$. Agitation speed and duration of the reaction were determined based on a preliminary study because they have little influence. These two factors are fixed at $500 \mathrm{rpm}$ and $60 \mathrm{~min}$ respectively.

\footnotetext{
${ }^{3} \mathrm{~d}_{\mathrm{i}}:$ partial desirability of response Yi

${ }^{4} \mathrm{di}_{\text {min }}$ : minimal partial desirability of response $\mathrm{Yi}$

$5 \mathrm{di}_{\max }$ : maximal partial desirability of response $\mathrm{Yi}$

${ }^{6}$ Cal. value: calculated value

${ }^{7}$ Exp. value: experimental value
} 


\section{References}

Amine, M., Asafar, F., Bilali, L., \& Nadifiyine, M. (2019). Hydrochloric Acid Leaching Study of Rare Earth Elements from Moroccan Phosphate. Journal of Chemistry. https://doi.org/10.1155/2019/4675276

Aouad, A., Benchanâa, M., Mokhlisse, A., \& Arafan, A. (2002). Study of thermal behaviour of organic matter from natural phosphates (Youssoufia-Morocco). Journal of thermal analysis and calorimetry, 70(2), 593-603. https://doi.org/10.1023/A:1021601329760

Aouad, A., Benchanâa, M., Mokhlisse, A., \& Ounas, A. (2004). Thermal analysis of Moroccan phosphates' Youssoufia'in an oxidative atmosphere by TG and DSC. Journal of Thermal Analysis and Calorimetry, 75(3), 887-900. https://doi.org/10.1023/b:jtan.0000027183.13313.c0

Baçaoui, A., Yaacoubi, A., Dahbi, A., Bennouna, C., Luu, R. P. T., Maldonado-Hodar, F. J., ... Moreno-Castilla, C. (2001). Optimization of conditions for the preparation of activated carbons from olive-waste cakes. Carbon, 39(3), 425-432. https://doi.org/10.1016/S0008-6223(00)00135-4

Bilali, L., Benchanaa, M., Outzourhit, A., \& Mokhlisse, A. (2008). Application of microwave technology to the heat treatment of natural Youssoufia (Morocco) phosphates. Journal of Microwave Power and Electromagnetic Energy, 43(2), 31-51. https://doi.org/10.1080/08327823.2008.11688608

Boujounoui, K., Abidi, A., Baçaoui, A., El Amari, K., \& Yaacoubi, A. (2018). Flotation process water recycling investigation for the complex draa sfar sulphide ore, Morocco. Mine Water and the Environment, 37(1), 75-87. https://doi.org/10.1007/s10230-017-0471-3

Chu, B., Shi, Y., Li, Z., Tian, H., Li, W., \& Wang, Y. (2015). Optimization of gentisides extraction from Gentiana rigescens Franch. ex Hemsl. by response surface methodology. Journal of Analytical Methods in Chemistry. https://doi.org/10.1155/2015/819067

El maguana,Y., Elhadiri, N., Bouchdoug, M., Benchanaa, M., \& Boussetta, A. (2018). Optimization of preparation conditions of novel adsorbent from sugar scum using response surface methodology for removal of methylene blue. Journal of Chemistry. https://doi.org/10.1155/2018/2093654

Hakkou, R., Benzaazoua, M., \& Bussière, B. (2016). Valorization of phosphate waste rocks and sludge from the Moroccan phosphate mines: challenges and perspectives. Procedia Engineering, 138, 110-118. https://doi.org/10.1016/j.proeng.2016.02.068

Hammas-Nasri, I., Horchani-Naifer, K., Férid, M., \& Barca, D. (2016). Rare earths concentration from phosphogypsum waste by two-step leaching method. International Journal of Mineral Processing, 149, $78-83$. https://doi.org/10.1016/j.minpro.2016.02.011

Koltun, P., \& Tharumarajah, A. (2014). Life cycle impact of rare earth elements. ISRn Metallurgy, 2014. https://doi.org/10.1155/2014/907536

Liu, G. Q., \& Wang, X. L. (2007). Optimization of critical medium components using response surface methodology for biomass and extracellular polysaccharide production by Agaricus blazei. Applied Microbiology and Biotechnology, 74(1), 78-83. https://doi.org/10.1007/s00253-006-0661-6

Loh, P. S., Chen, C. T. A., Anshari, G. Z., Lou, J. Y., Wang, J. T., Wang, S. L., \& Wang, B. J. (2016). Sedimentary organic matter and phosphate along the Kapuas River (west Kalimantan, Indonesia). Journal of Chemistry. https://doi.org/10.1155/2016/6874234

Mathieu, D., Mony, J., Phan Tan Luu, R., (2000). Logiciel de ge'ne'ration des matrices d'expe'riences en fonction des objectifs et traitement des réponses expérimentales, LPRAI, Marseille, France. https://www.nemrod.com/fr/software.

Pereira, F. (2003). Production d'acide phosphorique par attaque chlorhydrique de minerais phosphatés avec réduction des nuisances environnementales et récupération des terres rares en tant que sous-produits (Doctoral dissertation). https://tel.archives-ouvertes.fr/tel-00802984

Pereira, F., \& Bilal, E. (2012). Phosphoric acid extraction and rare earth recovery from apatites of the Brazilian phosphatic ores. https://hal.archives-ouvertes.fr/hal-00788958

Rollat, A. (2016). Recovery of rare earths from wet-process phosphoric acid, the Solvay experience. Procedia Engineering, 138, 273-280. https://doi.org/10.1016/j.hydromet.2009.11.017

Said, K. A. M., \& Amin, M. A. M. (2015). Overview on the response surface methodology (RSM) in extraction processes. Journal of Applied Science \& Process Engineering, 2(1). https://doi.org/10.33736/jaspe.161.2015 
Soltani, F., Abdollahy, M., Petersen, J., Ram, R., Koleini, S. J., \& Moradkhani, D. (2019). Leaching and recovery of phosphate and rare earth elements from an iron-rich fluorapatite concentrate: Part II: Selective leaching of calcium and phosphate and acid baking of the residue. Hydrometallurgy, 184, 29-38.

https://doi.org/10.1016/j.hydromet.2018.12.024

Wu, S., Zhao, L., Wang, L., Huang, X., Zhang, Y., Feng, Z., \& Cui, D. (2019). Simultaneous recovery of rare earth elements and phosphorus from phosphate rock by phosphoric acid leaching and selective precipitation: Towards green process. Journal of Rare Earths, 37(6), 652-658. https://doi.org/10.1016/j.jre.2018.09.012

Zhang, P. (2014). Comprehensive recovery and sustainable development of phosphate resources. Procedia Engineering, 83, 37-5. https://doi.org/10.1016/j.proeng.2014.09.010

Zhang, X., Gu, C., Ahmad, B., \& Huang, L. (2017). Optimization of extract method for Cynomorium songaricum Rupr. By response surface methodology. Journal of Analytical Methods in Chemistry. https://doi.org/10.1155/2017/6153802.

\section{Copyrights}

Copyright for this article is retained by the author(s), with first publication rights granted to the journal.

This is an open-access article distributed under the terms and conditions of the Creative Commons Attribution license (http://creativecommons.org/licenses/by/4.0/). 